\title{
PENGARUH VARIASI KONSENTRASI DAN LAMA PERENDAMAN ASAM LAKTAT TERHADAP KADAR GLUKOSA DAN KUALITAS TEPUNG UBI JALAR (Ipomoea batatas L)
}

\author{
Ruly Fitri Nurani \\ Pendidikan Biologi FPMIPA IKIP PGRI Madiun \\ Email : ruly.fitri@yahoo.com \\ Diterima 22 Desember 2015, Disetujui 10 Maret 2016
}

\begin{abstract}
Dependence on certain essential food commodities has led to the difficulty of overcoming food availability. One of the food that has potential as a substitute for staple foods are sweet potatoes. The purpose of this study was to determine the effect of variations in the lactic acid concentration and soaking time on the glucose contant and quality sweet potato flour. The research is quantitative with RAL factorial $2 \times 1$ in 3 times repetition. The factor of research are variation of lactic acid concentration $(0 \%, 0.5 \%, 1 \%$, and $1.5 \%)$ and variation of lactic acid soaking time (30 minutes, 60 minutes, 90 minutes).Research use titration Na-tiosulfat to collect the data of glucose contant. Anava two tail is used to examine the hypothesis continued with BNJ examination. The result of hypothesis shows that sig $t$ (variation of lactic acid concentration and variation of lactic acid soaking time) for glucose contant in sweet potato flour 0,000 with significance degree 0,05. From result above, the conclusion is variation of lactic acid concentration and variation of lactic acid soaking time affect the glucose contant and quality sweet potato flour.
\end{abstract}

Keywords : variation concentration, soaking time, glucose contant, quality sweet potato flour

\section{PENDAHULUAN}

Krisis ketersediaan pangan di Indonesia dapat menjadi ancaman yang sangat membahayakan jika tidak dilakukan upaya pencegahan dan penyelesaian. Ketergantungan pada komoditas pangan pokok tertentu menjadi salah satu penyebab sulitnya mengatasi ketersediaan pangan. Akibatnya pemerintah menjadi ketergantungan terhadap impor bahan pangan. Salah satu upaya untuk mengatasi ketersediaan pangan adalah dengan kembali pada sumber bahan pangan lokal yang ketersediaannya melimpah dan belum maksimal pemanfaatannya. Salah satu bahan pangan yang berpotensi sebagai pengganti pangan pokok adalah ubi jalar (Ipomoea batatas L). Indonesia adalah produsen ubi jalar terbesar keempat di dunia setelah Republik Rakyat Cina (RRC) dengan produktifitas 1,8 juta ton (FAO,
2010 dalam Kharinda, 2013). Berdasarkan data statistik, tingkat produksi ubi jalar (Ipomoea batatas L) di Indonesia pada tahun 2007 mencapai 1,886 juta ton dengan areal panen seluas 176,93 ribu ha (BPS, 2008 dalam Indrie 2009).

Ada beberapa jenis ubi jalar (Ipomoea batatas L). Jenis yang paling umum adalah ubi jalar putih, merah, ungu, kuning atau orange. Ubi Jalar (Ipomoea batatas L) banyak mengandung vitamin, mineral, fitokimia (antioksidan), dan serat (pektin, selulosa, hemiselulosa). Kandungan gizi ubi jalar (bukan yang berbentuk tepung) dalam 100 gr terdapat 76 kalori yang terdiri dari karbohidrat 17,6 $\mathrm{g}$, protein $1,57 \mathrm{~g}$, lemak $0,05 \mathrm{~g}$, serat $3 \mathrm{~g}$, kalsium $30 \mathrm{mg}$, zat besi 0,61 $\mathrm{mg}$, magnesium $25 \mathrm{mg}$, seng $0,30 \mathrm{mg}$, selenium 0,6 mcg, kalium $337 \mathrm{mg}$, vitamin C 22,7 mg dan juga terdapat Vit A. E, B-6 dan K 
dan tidak mengandung kolesterol (Budidaya Tanaman Umbi Organik, 2009).

Ubi jalar memiliki peran yang penting sebagai cadangan pangan bila diaplikasikan menjadi bahan pangan lain apabila produksi padi sudah tidak mencukupi lagi. Selama ini ubi jalar diolah dengan cara tradisional seperti kripik, ubi rebus, ubi goreng dan getuk. Ubi jalar bisa diaplikasikan menjadi bahan pangan yang lain apabila sudah dimodifikasi. Salah satu alternatif yang bisa dijadikan untuk mengurangi ketergantungan masyarakat terhadap salah satu bahan pangan pokok yaitu dengan dibuat menjadi tepung. Tepung ubi jalar masih memiliki karakteristik yang kurang dikehendaki yakni kurang dapat mengembang dan berwarna kecoklat-coklatan. Diperlukan suatu pengolahan untuk memperbaiki karakteristik tepung ubi jalar agar berkualitas, maka perlu dilakukan dengan cara memodifikasi sifat-sifat fungsional.

Salah satu teknik yang telah diterapkan untuk memodifikasi tepung singkong adalah fermentasi menggunakan bakteri asam laktat. Mikroba yang tumbuh menghasilkan enzim-enzim pektinolitik dan selulolitik yang dapat menghancurkan dinding sel singkong sedemikian rupa, sehingga terjadi pembebasan granula pati, hal ini yang akan menyebabkan perubahan karakteristik dari tepung yang dihasilkan. (Darti et al., 2013). Penelitian tepung sukun termodifikasi perendaman dengan asam laktat menyebabkan amilosa yang terhidrolisis akan terlarut, sehingga semakin menurun gula reduksi tepung sukun termodifikasi. Menurut Richana, et al., (2010), adakalanya pembentukan gula reduksi tidak banyak diharapkan karena gula reduksi merupakan oligosakarida yang sederhana yang mudah larut dalam air. Tepung sukun termodifikasi, lama perendaman asam laktat berpengaruh terhadap derajat putih. Perendaman akan mencegah reaksi maillard, sehingga semakin lama perendaman akan meningkatkan nilai derajat putih tepung sukun termodifikasi. Menurut Winarno (1992), reaksi maillard (pencoklatan non enzimatis) merupakan reaksi yang melibatkan gugus karbonil dan gugus anin. Salah satu cara untuk mencegah terjadinya pencoklatan dilakukan dengan cara menghambat atau memblokir reaksi antara gugus karbonil atau gula pereduksi dengan gugus amina dengan melakukan perendaman, sehingga sengat efektif untuk mencegah terjadinya perubahan derajat putih. (Feny et al., 2013).

\section{METODE PENELITIAN}

Rancangan percobaan yang digunakan adalah Rancangan Acak Lengkap (RAL) disusun secara 2 faktorial dengan 3 kali ulangan. Faktor perlakuan meliputi konsentrasi asam laktat dan lama perendaman asam laktat. Variabel bebas meliputi macam-macam konsentrasi dan lama perendaman asam laktat sedangkan variabel terikat meliputi kadar glukosa dan kualitas tepung. Berdasarkan faktor perlakuan didapatkan 9 kombinasi yaitu $\mathrm{K}_{1} \mathrm{~L}_{1}, \mathrm{~K}_{1} \mathrm{~L}_{2}, \mathrm{~K}_{1} \mathrm{~L}_{3}, \mathrm{~K}_{2} \mathrm{~L}_{1}, \mathrm{~K}_{2} \mathrm{~L}_{2}, \mathrm{~K}_{2} \mathrm{~L}_{3}, \mathrm{~K}_{3} \mathrm{~L}_{1}$, $\mathrm{K}_{3} \mathrm{~L}_{2}, \mathrm{~K}_{3} \mathrm{~L}_{3}$. Variasi konsentrasi yang digunakan adalah $1 \%, 1,5 \%$ dan $2 \%$. Lama perendaman yang digunakan adalah 60 menit, 90 menit dan 120 menit.

Teknik pengumpulan data yang digunakan untuk mengetahui kadar glukosa adalah dengan metode luff schrool sedangkan pengumpulan data untuk uji organoleptik dengan pengisian angket oleh 15 panelis. Ubi jalar yang direndam dengan konsentrasi $1 \%, 1,5 \%$ dan $2 \%$ serta lama perendaman 60 menit, 90 menit dan 120 menit diambil sebanyak 5 gram. Rumus yang digunakan untuk menghitung kadar glukosa adalah

Kadar Glukosa $=\frac{\text { At } x \text { Fp }}{\text { mgr sampel }} \times 100 \%$ 
Rumus untuk mencari nilai organoleptik adalah

$\mathrm{N}=\frac{\sum x w a r n a(30)+\sum x b a u(20)+\sum x t e k s t u r(20)}{70}$

Alat yang digunakan selama penelitian berlangsung adalah pisau, ember, oven, blender, penyaring, neraca, labu ukur, pipet ukur, corong gelas, erlenmeyer, pendingin balik, pemanas, biuret, pengaduk kaca, kertas $\mathrm{pH}$, pipet tetes, stopwatch, batu didih, dan kasa asbes. Bahan yang digunakan adalah ubi jalar segar, asam laktat dengan konsentrasi $1 \%, 2 \%$ dan $3 \%$, air, aquades, $\mathrm{Pb}$ asetat, larutan luff scoorl, Na Fosfat $8 \%$, KI 20\%, $\mathrm{H} 2 \mathrm{SO} 426,5 \%$, amilum $1 \%$ dan $\mathrm{Na} 2 \mathrm{~S} 2 \mathrm{O} 3$ $0,1 \mathrm{~N}$. Prosedur penelitian adalah ubi jalar dikupas kemudian dirajang tipis-tipis atau disawut, lalu ubi jalar di rendam dengan menggunakan asam laktat dengan konsentrasi 1\%, 2\% dan 3\%. Proses perendaman dilakukan dengan waktu yang berbeda yaitu 30 menit, 60 menit dan 90 menit. Perendaman dilakukan di dalam oven dengan suhu $45^{\circ} \mathrm{C}$, kemudian oven dengan suhu $45^{\circ} \mathrm{C}$ selama 6 jam, selanjutnya ubi jalar di giling dengan menggunakan blender serta diayak agar butiran tepung menjadi lebih halus. Tepung ubi jalar di uji kadar glukosanya. Pengujian organoleptik dengan memberikan sampel dan angket kepada 15 orang panelis untuk diamati dengan nilai skor yang sudah ditentukan. Proses pengambilan data dilakukan dengan teknik titrasi Na-tiosulfat untuk mengetahui kadar glukosa tepung ubi jalar.Teknik analisis data menggunakan anava dua jalur dan uji BNJ dengan taraf signifikan 5\% dilakukan jika hasil penelitian signifikan. Seluruh data yang diperoleh saat penelitian dianalisis dengan Analisis Variansi (ANAVA) dua jalur dengan program komputer SPSS for windows.

\section{HASIL DAN PEMBAHASAN}

\section{Kadar Glukosa}

Data analisis kadar glukosa pada tepung ubi jalar diperoleh dari hasil titrasi melalui 3 kali ulangan. Data dapat dilihat pada Tabel 1

Tabel 1. Kadar Glukosa

\begin{tabular}{cccccc}
\hline \multirow{2}{*}{ Perlakuan } & \multicolumn{3}{c}{ Ulangan } & Rata-rata & $\begin{array}{c}\text { Kadar } \\
\text { glukosa }(\%)\end{array}$ \\
\cline { 2 - 4 } & $\mathrm{I}$ & $\mathrm{II}$ & $\mathrm{III}$ & & $2,88 \%$ \\
$\mathrm{~K}_{1} \mathrm{~L}_{1}$ & 19,3 & 19,3 & 19,2 & 19,2667 & $2,04 \%$ \\
$\mathrm{~K}_{1} \mathrm{~L}_{2}$ & 20,0 & 20,0 & 19,9 & 19,9667 & $2,9,92 \%$ \\
$\mathrm{~K}_{1} \mathrm{~L}_{3}$ & 20,0 & 20,2 & 20,1 & 20,1000 & $1,92 \%$ \\
$\mathrm{~K}_{2} \mathrm{~L}_{1}$ & 19,4 & 19,5 & 20,4 & 19,7667 & $2,28 \%$ \\
$\mathrm{~K}_{2} \mathrm{~L}_{2}$ & 19,9 & 20,2 & 20,2 & 20,1000 & $1,92 \%$ \\
$\mathrm{~K}_{2} \mathrm{~L}_{3}$ & 19,7 & 19,8 & 19,9 & 19,8000 & $1,32 \%$ \\
$\mathrm{~K}_{3} \mathrm{~L}_{1}$ & 20,5 & 20,4 & 20,7 & 20,5333 & $2,04 \%$ \\
$\mathrm{~K}_{3} \mathrm{~L}_{2}$ & 20,3 & 20,3 & 20,2 & 20,2667 & $1,68 \%$ \\
$\mathrm{~K}_{3} \mathrm{~L}_{3}$ & 20,6 & 20,7 & 20,8 & 20,7000 & $1,2 \%$ \\
\hline
\end{tabular}

\section{Variasi Konsentrasi}

Gambar 1 kadar glukosa tertinggi terdapat pada konsentrasi $1 \%$ yaitu 2,88 $\%$, kadar glukosa terendah terdapat pada konsentrasi $2 \%$ yaitu 1,2\%. Kandungan pati yang terdapat di dalam tepung ubi jalar tersusun oleh polisakarida amilosa dan amilopektin. Molekul amilosa mudah 
terpecah dibanding dengan molekul amilopektin sehingga saat hidrolisa asam berlangsung akan menurunkan gugus amilosa. Hasil penelitian ini sesuai pada penelitian tepung sukun termodifikasi yang dilakukan oleh Feny et al., (2013) yang menjelaskan bahwa pada tepung sukun termodifikasi, peningkatan konsentrasi asam laktat yang digunakan berpengaruh terhadap penurunan gula reduksi. Hal ini terjadi karena semakin tinggi konsentrasi asam laktat maka semakin banyak polisakarida yang terhidrolisis dan terlarut.

Polisakarida berupa amilosa yang terhidrolisis dan terlarut semakin banyak maka menyebabkan gula reduksi pada tepung sukun termodifikasi semakin sedikit. Pati yang terdapat dalam sukun tersusun oleh polisakarida amilosa dan amilopektin. Molekul amilosa mudah terpecah dibanding dengan molekul amilopektin sehingga saat hidrolisa asam berlangsung akan menurunkan gugus amilosa (Atichokudomchaia, et al., 2000 dalam Pudjihastuti, 2010). Perendaman asam laktat, asam yang berdifusi ke dalam granula pati akan membuat molekulmolekul pati menjadi lebih kecil dan mudah larut dalam air (Demeate, et al., 1999 dalam Pudjihastuti, 2010). Peningkatan kadar glukosa pada konsentrasi $1 \%\left(\mathrm{~K}_{1} \mathrm{~L}_{1}\right)$ dan $1,5 \%\left(\mathrm{~K}_{2} \mathrm{~L}_{2}\right)$ dikarenakan semakin kecil konsentrasi asam laktat maka semakin tinggi kadar glukosanya. yaitu $1,2 \%$. Peningkatan kadar glukosa dikarenakan polisakarida terhidrolisis oleh asam, sehingga banyak gugus amilosa yang terlarut dalam air rendaman dan kandungan glukosa pada tepung rendah. Hasil penelitian ini sesuai pada penelitian tepung sukun termodifikasi yang dilakukan oleh Feny et al., (2013) bahwa lama perendaman asam laktat berpengaruh terhadap penurunan gula reduksi.

\section{Lama Perendaman}

Tabel 1 menggambarkan bahwa kadar glukosa tertinggi terdapat pada lama perendaman 60 menit yaitu 2,88\% sedangkan untuk kadar glukosa terendah terdapat pada lama perendaman 120 menit Perendaman dengan asam laktat menyebabkan amilosa yang terhidrolisis akan terlarut, sehingga semakin lama perendaman menyebabkan semakin menurun gula reduksi tepung sukun termodifikasi.

\section{Uji Organoleptik}

Adapun data hasil uji organoleptik dapat dilihat pada Tabel 2 .

Tabel 2. Hasil Uji Organoleptik

\begin{tabular}{ccccc}
\hline & \multicolumn{4}{c}{ Rata-rata uji } \\
organoleptik & \multirow{2}{*}{ Nerlakuan } \\
\cline { 2 - 4 } & $\begin{array}{c}\text { Warna } \\
(30)\end{array}$ & $\begin{array}{c}\text { Bau } \\
20)\end{array}$ & $\begin{array}{c}\text { Tekstur } \\
(20)\end{array}$ & \\
\hline $\mathrm{K}_{1} \mathrm{~L}_{1}$ & 1,6 & 3,1 & 1,9 & 1,9 \\
$\mathrm{~K}_{1} \mathrm{~L}_{2}$ & 3 & 1,6 & 2 & 2,3 \\
$\mathrm{~K}_{1} \mathrm{~L}_{3}$ & 3,3 & 3,3 & 1,5 & 2,7 \\
$\mathrm{~K}_{2} \mathrm{~L}_{1}$ & 2,5 & 2,5 & 2,2 & 2,4 \\
$\mathrm{~K}_{2} \mathrm{~L}_{2}$ & 3,5 & 2,3 & 2,1 & 2,7 \\
$\mathrm{~K}_{2} \mathrm{~L}_{3}$ & 1,6 & 2,0 & 2,9 & 2,0 \\
$\mathrm{~K}_{3} \mathrm{~L}_{1}$ & 1,6 & 2,2 & 2,1 & 2,1 \\
$\mathrm{~K}_{3} \mathrm{~L}_{2}$ & 3,1 & 3,1 & 2,7 & 2,9 \\
$\mathrm{~K}_{3} \mathrm{~L}_{3}$ & 3,6 & 3,3 & 2,9 & 3,3 \\
\hline
\end{tabular}

Hasil nilai organoleptik tepung dapat dilihat pada Gambar 1.

Uji organoleptik pada suatu produk perlu dilakukan untuk menilai seberapa besar minat konsumen terhadap produk yang dihasilkan. Panelis akan memberi penilaian khusus terhadap warna, tekstur dan bau tepung ubi jalar. Pengujian organoleptik dilakukan untuk mengetahui penilaian masing-masing terhadap tepung ubi jalar yang diujikan. Hasil uji organoleptik warna tepung ubi jalar mengacu pada skala hedonik yaitu 4 (sangat putih), 3 (putih), 2 (tidak putih), dan 1 (coklat keputihan). Perlakuan $\mathrm{K}_{3} \mathrm{~L}_{3}$ (konsentrasi 120 menit dengan lama 
perendaman 120 menit) memiliki nilai tertinggi yaitu 3,3. Sedangkan perlakuan

$\mathrm{K}_{1} \mathrm{~L}_{1}$ memiliki nilai terendah yaitu 1,9 .

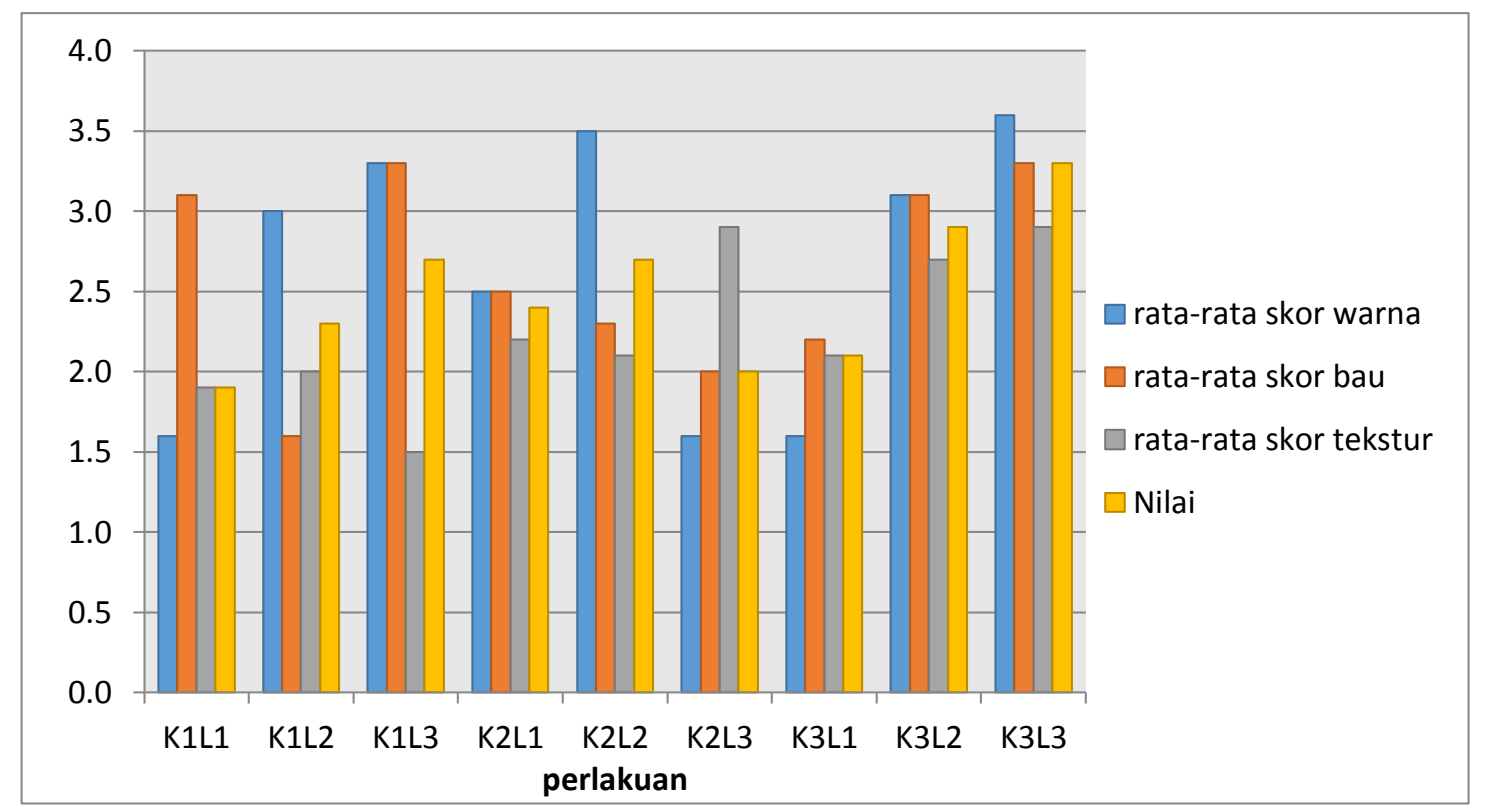

Gambar 1. Nilai Organoleptik Tepung

Berdasarkan data tersebut dapat dilihat bahwa semakin tinggi konsentrasi asam laktat dan lama perendaman maka semakin meningkat warna tepung ubi jalar. Hasil penelitian didukung pada penelitian tepung sukun termodifikasi, lama perendaman asam laktat berpengaruh terhadap peningkatan derajat putih. Perendaman akan mencegah reaksi maillard, sehingga semakin lama perendaman akan meningkatkan nilai derajat putih tepung sukun termodifikasi. Menurut Winarno (1992), reaksi maillard (pencoklatan non-enzimatis) merupakan reaksi yang melibatkan gugus karbonil dan gugus amin. Salah satu cara untuk mencegah terjadinya reaksi pencoklatan dilakukan dengan cara menghambat atau memblokir reaksi antara gugus karbonil atau gula pereduksi dengan gugus amina dengan melakukan perendaman, sehingga sangat efektif untuk mencegah terjadinya perubahan derajat putih.

Hasil uji organoleptik terhadap aroma bertujuan untuk mengetahui tingkat respon dari panelis mengenai kesukaannya terhadap tepung ubi jalar pada masingmasing perlakuan. Hasil dari uji organoleptik bau dari tepung ubi jalar mengacu pada skala hedonik yaitu 4 (tidak berbau), 3 (agak kuat), 2 (kurang kuat), dan 1 (sangat kuat). Pada perlakuan $\mathrm{K}_{3} \mathrm{~L}_{3}$ (konsentrasi 2\% dengan lama perendaman 120 menit) memiliki rata-rata tertinggi 3,3 sedangkan $\mathrm{K}_{1} \mathrm{~L}_{2}$ (konsentrasi $1 \%$ dengan lama perendaman 90 menit) memiliki ratarata terendah yaitu 1,6. Bau yang dihasilkan dari makanan banyak menentukan kelezatan bahan pangan tersebut. Senyawa asam bercampur dalam tepung, sehingga tepung menghasilkan aroma dan citarasa yang khas yang dapat menutupi citarasa dari umbi yang cenderung tidak disukai oleh konsumen (Sarpina et al., dalam Yoas, Lindayani, Laksmi., 2012).

Hasil uji organoleptik tekstur dari tepung ubi jalar yang mengacu pada skala hedonik yaitu 4 (sangat lembut), 3 (lembut), 2 (kasar) dan 1 (sangat kasar) 
menunjukkan perlakuan $\mathrm{K}_{3} \mathrm{~L}_{3}$ (konsentrasi $2 \%$ dengan lama perendaman 120 menit) memiliki rata-rata tertinggi 2,9 berarti termasuk dalam agak lembut namun mendekati lembut, sedangkan $\mathrm{K}_{1} \mathrm{~L}_{3}$ (konsentrasi 1\% dengan lama perendaman 120 menit) memiliki rata-rata terendah yaitu 1,5. Tekstur memiliki pengaruh penting terhadap tepung ubi jalar misalnya dari tingkat kelembutan, kekasaran dan sebagainya. Panelis cenderung lebih menyukai tekstur yang lembut dan tidak kasar. Sebaliknya, panelis akan memberi skor yang lebih rendah terhadap tepung ubi jalar yang teksturnya kasar. Tekstur merupakan sensasi tekanan yang dapat diamati dengan mulut (pada waktu digigit, dikunyah, dan ditelan) ataupun perabaan dengan jari (Kartika, et al., 1988 dalam Yaumil 2012). Hal ini didukung oleh pendapat Demeate, et al.,(1999) (dalam Pudjihastuti, 2010) menyatakan bahwa pada perendaman dengan asam laktat, asam yang berdifusi ke dalam granula pati akan membuat molekul-molekul pati menjadi lebih kecil dan mudah larut dalam air.

Interaksi antara kadar glukosa dan uji organoleptik tepung ubi jalar (Ipomoea batatas $\mathbf{L}$ )
Berdasarkan data kadar glukosa dan data uji organoleptik dapat dilihat interaksi antara kadar glusoka dan uji organoleptik. Adapun data interaksi dapat dilihat pada tabel 3.

Tabel 3. Interaksi Kadar Glukosa dan Uji Organoleptik

\begin{tabular}{ccc}
\hline Perlakuan & $\begin{array}{c}\text { Kadar } \\
\text { glukosa } \\
(\%)\end{array}$ & $\begin{array}{c}\text { Uji } \\
\text { organoleptik }\end{array}$ \\
\hline $\mathrm{K}_{1} \mathrm{~L}_{1}$ & $2,88 \%$ & 1,9 \\
$\mathrm{~K}_{1} \mathrm{~L}_{2}$ & $2,04 \%$ & 2,3 \\
$\mathrm{~K}_{1} \mathrm{~L}_{3}$ & $1,92 \%$ & 2,7 \\
$\mathrm{~K}_{2} \mathrm{~L}_{1}$ & $2,28 \%$ & 2,4 \\
$\mathrm{~K}_{2} \mathrm{~L}_{2}$ & $1,92 \%$ & 2,7 \\
$\mathrm{~K}_{2} \mathrm{~L}_{3}$ & $1,32 \%$ & 2,0 \\
$\mathrm{~K}_{3} \mathrm{~L}_{1}$ & $2,04 \%$ & 2,1 \\
$\mathrm{~K}_{3} \mathrm{~L}_{2}$ & $1,68 \%$ & 2,9 \\
$\mathrm{~K}_{3} \mathrm{~L}_{3}$ & $1,2 \%$ & 3,3 \\
\hline
\end{tabular}

Berdasarkan hasil uji kadar glukosa dan uji organoleptik tepung ubi jalar dapat dilihat adanya interaksi antara kadar glukosa dan nilai organoleptik. Data interaksi dapat dilihat pada Gambar 2

Berdasarkan

Gambar 2 menunjukkan bahwa panelis lebih suka pada perlakuan $\mathrm{K}_{3} \mathrm{~L}_{3}$ yang memiliki kadar glukosa terendah yaitu $1,12 \%$ dan kualitas tepung yang berkualitas dengan nilai 3,3.

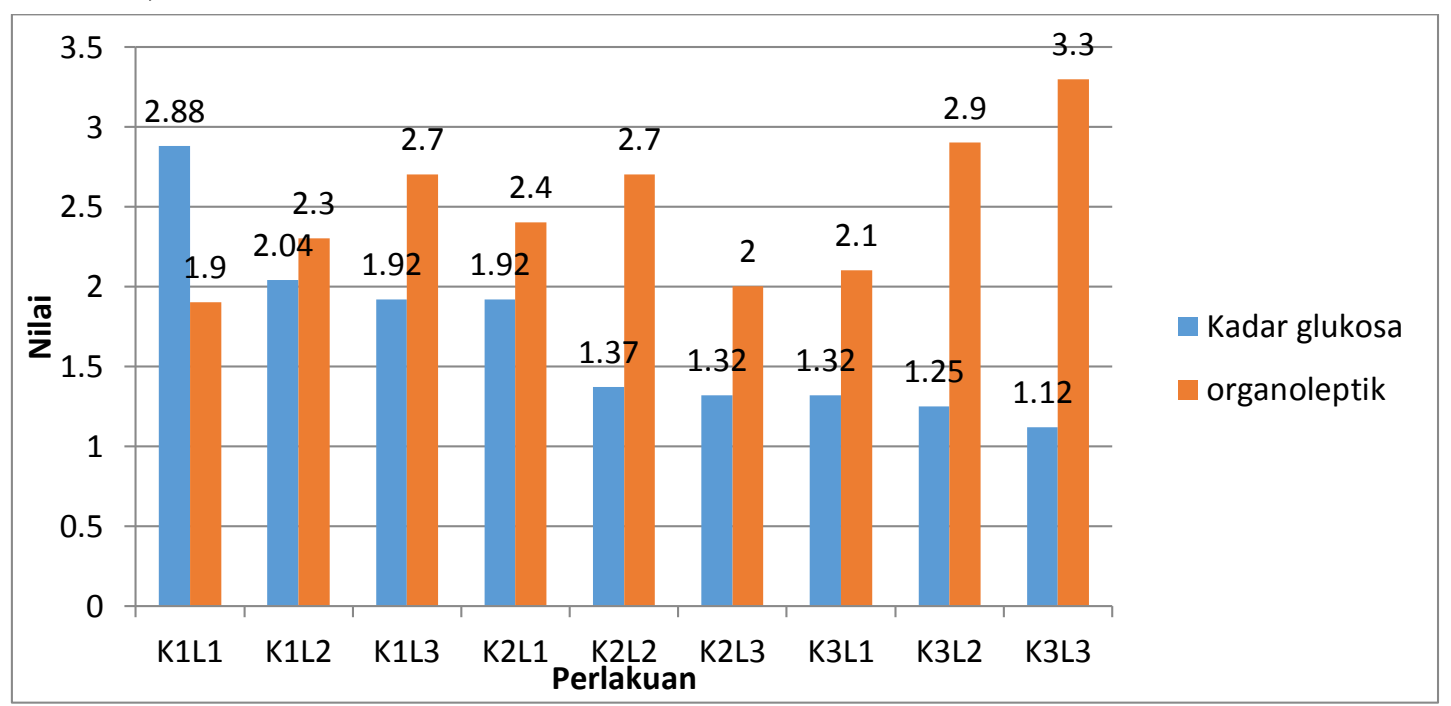

Gambar 2. Interaksi Kadar Glukosa dan Uji Organoleptik 
Sedangkan perlakuan yang tidak disukai oleh panelis adalah perlakuan $\mathrm{K}_{1} \mathrm{~L}_{1}$ yang memiliki kadar glukosa tertinggi yaitu $2,88 \%$ dan kualitas tepung rendah dengan nilai 1,9 . Organoleptik yang paling disukai oleh panelis adalah pada perlakuan $\mathrm{K}_{3} \mathrm{~L}_{3}$ yang memiliki karakteristik warna sangat putih, baunya yang dari khas tepung ubi jalar menjadi tidak berbau dan teksturnya yang sangat lembut.

\section{KESIMPULAN DAN SARAN}

\section{Simpulan}

Variasi konsentrasi dan lama perendaman asam laktat memberikan pengaruh terhadap kadar glukosa pada tepung ubi jalar (Ipomoea batatas L), terdapat interaksi antara variasi konsentrasi dan lama perendaman terhadap kadar glukosa tepung ubi jalar (Ipomoea batatas L). Semakin tinggi konsentrasi dan lama perendaman asam laktat maka memberikan tingkat kesukaan panelis terhadap kualitas (warna, bau, tekstur) pada tepung ubi jalar (Ipomoea batatas L).

\section{Saran}

Pada pembuatan tepung ubi jalar yang dipengaruhi oleh variasi konsentrasi asam laktat dan lama perendaman sebaiknya menggunakan konsentrasi asam laktat $2 \%$ dengan lama perendaman 120 menit. Perlu diteliti lebih lanjut pengaruh variasi konsentrasi dan lama perendaman asam laktat menggunakan jenis ubi yang lainnya.

\section{DAFTAR PUSTAKA}

Darti, Setiarti, dan Intan. (2013). Optimasi proses produksi tepung talas (Colocasia esculenta, L. Schoot) termodifikasi secara fermentasi. http://portal.kopertis3.or.id. Diakses tanggal 7 Maret 2014
Feny, B., dan Dimas. (2013). Kajian Karakteristik Fisikokimia Tepung Sukun (Artocarpus Communis) Termodifikasi Dengan Variasi Konsentrasi Dan Lama Perendaman Asam Laktat.www.ilmu pangan.fp.uns.ac.id. Diakses tanggal 17 Februari 2014

Indrie. (2009). Rekomendasi Dalam Penetapan Standar Mutu Tepung Ubi Jalar. http://jateng.litbang.deptan.go.id. Diakses tanggal 7 maret 2014

Kharinda dkk. (2013). Studi Perubahan sifat kimia tepung ubi jalar putih (Ipomoea batatas Var. Sukuh) sebagai efek modifikasi menggunakan metode heat moisture treatment. http://repository.ipb.ac.id. Diakes tanggal 6 maret 2014

Yaumil Rakhmah. (2012). Studi Pembuatan Bolu Gulung dari Tepung Ubi Jalar (Ipomoea batatas L). Skripsi tidak dipublikasikan repository.unhas.ac.id. Diakses tanggal 24 April 2012

Yoas, Lindayani, Laksmi. (2010). Karakter Kimia Dan Fisik Tepung Garut (Maranta Arundinaceae) Hasil Fermentasi Dan Aplikasinya Sebagai Alternatif Pengganti Tepung Terigu Dalam Pembuatan Pasta Instan.http://eprints.unika.ac.id. Diakses tanggal 27 Februari 2014 